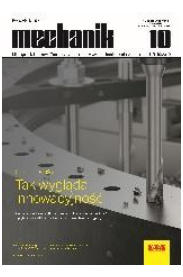

How to cite this article:

Authors: Mariusz Deja, Alicja Stanisławska, Marek Szkodo, Karolina Wszelak

Title of article: „Forming the surface layer properties during grinding”

Mechanik, No. 10 (2019)

DOI: https://doi.org/10.17814/mechanik.2019.10.88

\title{
Forming the surface layer properties during grinding
}

\author{
MARIUSZ DEJA \\ ALICJA STANISEAWSKA \\ MAREK SZKODO \\ KAROLINA WSZELAK *
}

Dr hab. inż. Mariusz Deja (mariusz.deja@pg.edu.pl), https://orcid.org/0000-0002-1874-9015 - Katedra Technologii Maszyn i Automatyzacji Produkcji, Wydział Mechaniczny Politechniki Gdańskiej, Gdańsk, Polska

Mgr inż. Alicja Stanisławska (alicja.stanislawska@pg.edu.pl), https://orcid.org/0000-0003-0646-4706 - Katedra Technologii Maszyn i Automatyzacji Produkcji, Wydział Mechaniczny Politechniki Gdańskiej, Gdańsk, Polska

Dr hab. inż. Marek Szkodo (marek.szkodo@pg.edu.pl), https://orcid.org/0000-0002-4210-0718 - Katedra Inżynierii Materiałowej i Spajania, Wydział Mechaniczny Politechniki Gdańskiej, Gdańsk, Polska

Mgr inż. Karolina Wszelak (karolina.wszelak@pg.edu.pl), https://orcid.org/0000-0001-5463-025X - Katedra Technologii Maszyn i Automatyzacji Produkcji, Wydział Mechaniczny Politechniki Gdańskiej, Gdańsk, Polska

The article describes the grinding of flat surfaces combined with changes in the properties of the surface layer, in particular through its hardening. Issues related to the grind-hardening technology are discussed. In addition, tests have been presented in which improved grinding properties of the workpiece through plastic deformation have been obtained after the grinding process.

KEYWORDS: grinding, hardening, surface, grind-hardening

\section{Introduction}

Increasing technological requirements and increasingly complex shapes of objects - such as gears [1] or turbine blades [2] - necessitate the use of special machines and tools, as well as precise selection of grinding or milling parameters [3]. For economic reasons, the smallest number of grinding wheel passes [4] is sought while maintaining satisfactory surface quality. Grinding combined with hardening the surface layer of the workpiece, so-called grind-hardening allows not only to minimize costs, but also to reduce machining time, because it eliminates the need for a separate hardening operation after the grinding process. Another technological solution, without disadvantages of grinding with hardening, is grinding, after which better properties of the surface layer are obtained due to plastic deformation without hardening of the surface [5].

\section{Grinding with hardening of the top layer}

Grind-hardening (fig. 1) is a hybrid production process, during which the machined surface is simultaneously ground and hardened. The hardening process during grinding requires a structural transformation of the workpiece material, which uses the heat generated in the grinding zone. During grinding, the surface layer of the object is heated above the austenization temperature, and then as a result of hardening, martensitic transformation occurs on the surface. These changes are possible due to the selection of appropriate machining parameters, such as cutting depth and feedrate. Martensitic phase transformation can occur due to the use of appropriately large values of cutting depth and feedrate in the workpiece, which increases the hardness of the surface layer [6]. 


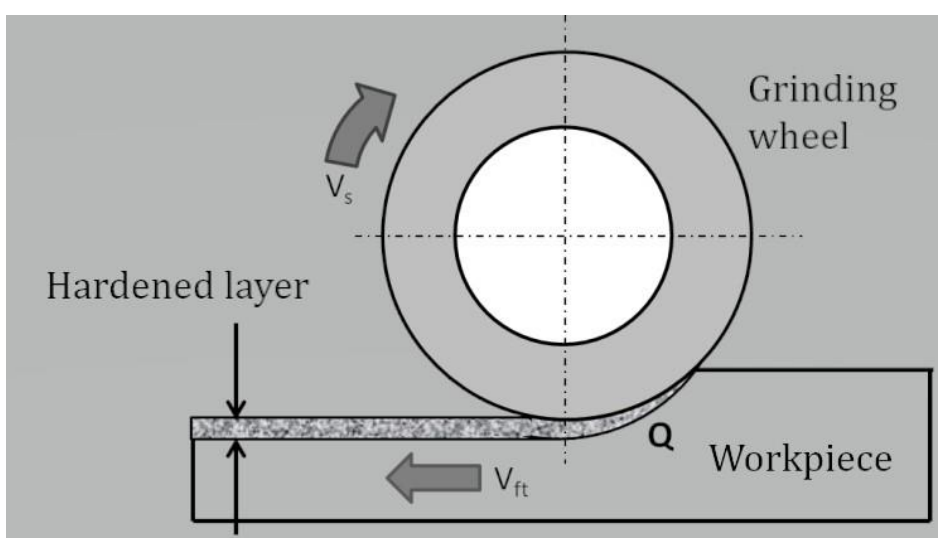

Fig. 1. Grind-hardening

Grinding technology combined with hardening was introduced in the late 20th century by Brinksmeier and Brockhoff [7]. In the initial phase, this process was tested in an experimental manner to confirm its feasibility [8].

\section{Issues of grind-hardening technology}

Grind-hardening technology has many advantages, but it is not without drawbacks. The main advantage is the lack of the need for an additional hardening operation after grinding of the top surface layer. The disadvantages include reduced surface quality of the workpiece as well as lower dimensional and shape accuracy, which often results in the need for an additional, second grinding. During the second finishing grinding, however, the top surface layer partially loses its properties due to tempering of martensite, which reduces its hardness. A new interface is created in the workpiece - between the martensite and perlite grains. This phenomenon may have an adverse effect on the distribution of self-stress, which in the future may result in a reduction of the product's service life. The key element of this technology is the selection of appropriate process input parameters that will ensure obtaining the assumed thickness of the hardened layer. Available literature presents a number of issues related to the grinding process combined with hardening. Salonitis et al. presented, among others, topics of thermal analysis of the process [9], the impact of the coolant [10], the importance of the type of grinding wheel [11] or grinding force [12], as well as the simulation of residual stress [6].

\section{Depth of hardened surface layer}

The key problem in grinding combined with hardening is the selection of process technological parameters that would ensure obtaining the desired depth of the hardened surface layer - HPD (hardness penetration depth). Part of the research is focused on checking the maximum efficiency of the process, in which different grinding wheels or combinations of input parameters are used [8,11,13-15]. Data cited in the literature indicate that when increasing the depth of cut - while maintaining a constant feed speed - HPD increases, while with the same depth of grinding, the depth of the hardened surface layer increases as a result of reducing the feedrate $[16,17]$.

After obtaining the desired hardened layer, another problem arises associated with the need to regrind in order to obtain the required dimensional and shape accuracy. During this process, high temperatures can soften the workpiece material as well as create adverse tensile stresses or cracks. In this situation, numerical and analytical models have been proposed to predict surface temperature during the process and its consequences [18-20]. Results presented in the paper by Alonso et al. [21] show the relationship between proper grinding energy and HPD depth. This correlation is appropriate to predict the results of both hardening and subsequent grinding - finishing. It is independent of other machining parameters, i.e. cutting depth, feedrate and grinding wheel rotational speed.

Fig. 2 presents examples of relationships between HPD and specific surface energy of grinding, obtained in the studies of Alonso et al. [21]. These relationships are approximately linear, and in addition, it is possible to estimate the slope of the curves based on chemical composition of the material being analyzed. 


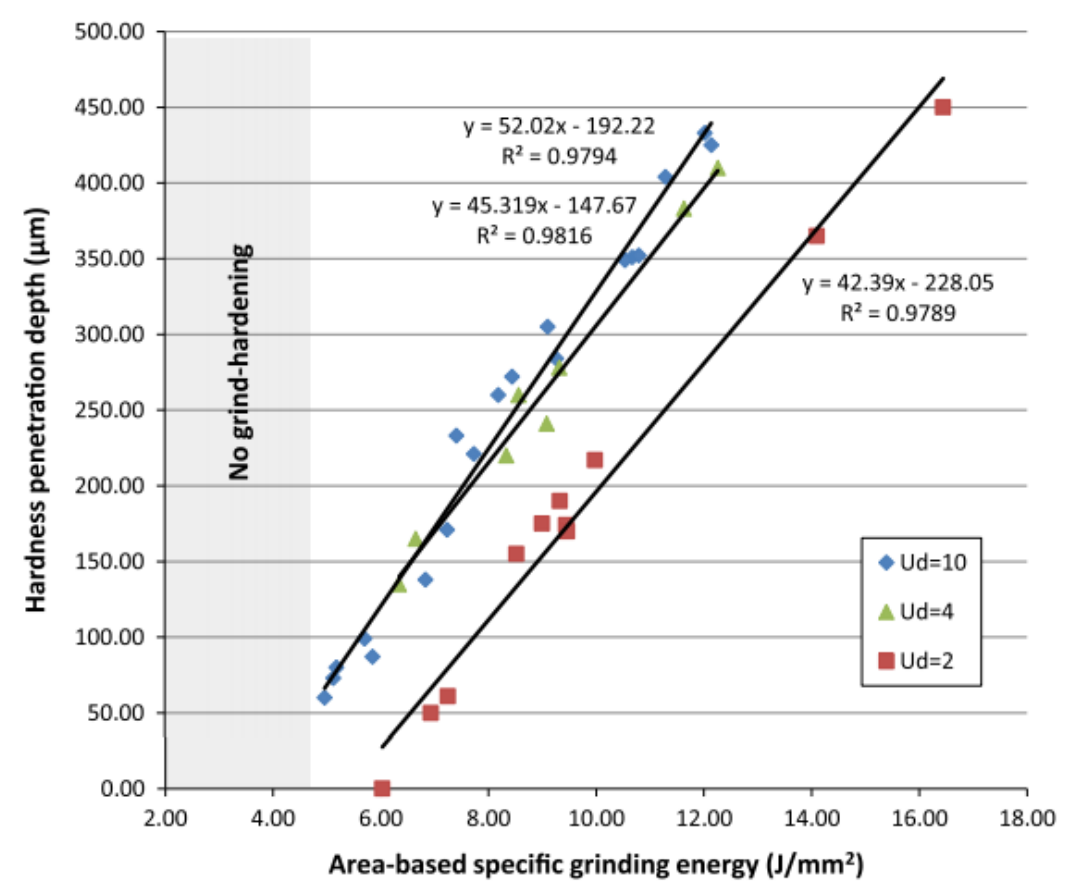

Fig. 2. Influence of surface grinding energy on the depth of hardening of the surface layer for AISI 1045 steel [21]

\section{Residual stress}

Residual stresses in the surface layer of the workpiece are caused by heat dissipation in the grinding zone, pressure between the grinding wheel and the workpiece and phase change of the material [22]. The equilibrium of these three elements determines whether the tensions will be tensile or compressive.

Paper [23] pointed out that the pressure caused by tension of the grinding wheel on the workpiece generates compressive residual stresses. Thermal deformation causes tensile residual stresses. Salonitis, in paper [6], presented FEM modeling of residual stress distributions generated during grinding with hardening and experimental results. In the case of grinding without the use of coolant, tensile stresses are present in the entire heat treated layer, while in the case of hardened grinding with the use of coolant, residual stresses are compressive and maximally cover an area up to $1 / 4$ of the hardened layer.

\section{Grinding with hardening of the surface layer through plastic deformation}

The work [5] presents results of research on the impact of concurrent grinding depths of flat surfaces on the roughness and nano-hardness of the surface layer of C45 steel with a ferritic-pearlitic structure and an average grain size of $20 \mu \mathrm{m}$. For all applied values of the grinding depth $a e=0.002 ; 0.008 ; 0.014$ and $0.020 \mathrm{~mm}$, significant increase in the hardness of the surface layer of the workpiece was obtained despite the lack of hardening. Grinding was carried out on a SPG $25 \times 60 \mathrm{CNC}$ surface grinder with a horizontal spindle axis. A Norton grinding wheel with fine alumina grains with 38A60LVS technical characteristics and dimensions $(\mathrm{D} \times \mathrm{T} \times \mathrm{H}) 250 \times 25 \times 76.2$ $\mathrm{mm}$ was used for machining. Each test was preceded by conditioning of the grinding wheel with a single-grained diamond dresser. Concurrent plunge grinding was carried out using a coolant at a constant grinding wheel peripheral speed $v s=25 \mathrm{~m} / \mathrm{s}$ and a constant feed speed $v f t=1 \mathrm{~m} / \mathrm{min}$.

Metallographic examination of the surface layer of the ground object with a depth of $a e=20 \mu \mathrm{m}$, performed under the JEOL JSM-7800 F scanning electron microscope, showed an additional layer of changed material with a clear separation border from ferrite and perlite grains (fig. 3). The layer adhered well to the ferritic-pearlitic substrate, and in some places was clearly cracked. As demonstrated by chemical composition studies using EDS X-ray energy spectroscopy (fig. 4), this layer was made of oxygen atoms (approximately 30\% by mass) and iron atoms (approximately $70 \%$ by mass). Analyzing the Fe-O phase equilibrium plot (fig. 5), one can put forward the thesis that after grinding with $a e=20 \mu \mathrm{m}$ depth the steel surface has an $\mathrm{Fe}_{2} \mathrm{O}_{3}$ oxide film.

As demonstrated in [24], hematite begins to crystallize at $420^{\circ} \mathrm{C}$. Considering the fact that during grinding the heating rate of the surface layer of the machined material is high, the temperature of hematite crystallization onset had to be much higher than $420^{\circ} \mathrm{C}$. In addition, the hematite layer formed was about $3 \div 4 \mu \mathrm{m}$ thick, which also required much higher temperature than the initial temperature of oxide crystallization. At the same time, 
heating temperature of the surface layer of the ground material did not cause the conversion of perlite to austenite, therefore it did not exceed $728{ }^{\circ} \mathrm{C}$, and taking into account that the rapid heating of steel shifts the beginning of the pearlitic transformation towards a higher temperature, it was not higher than $900{ }^{\circ} \mathrm{C}$.

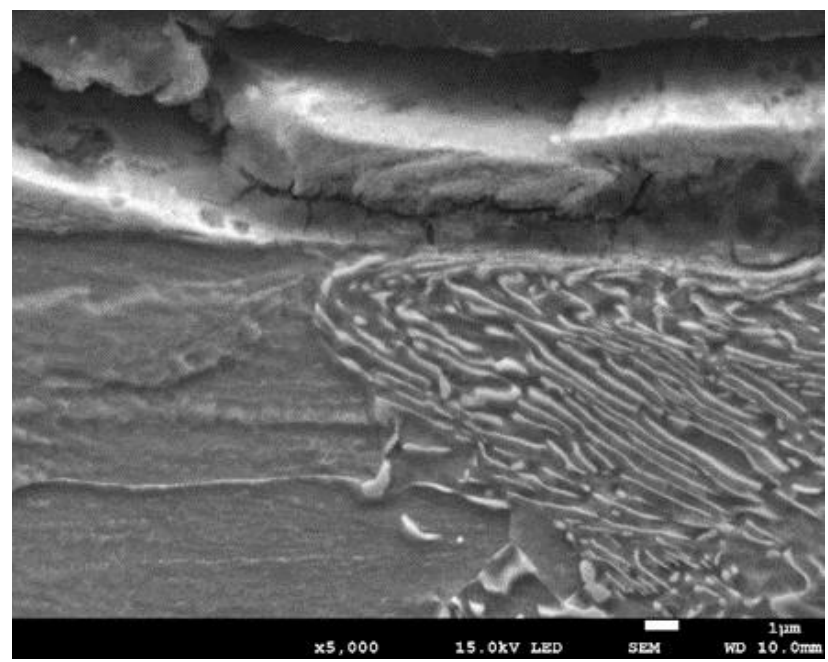

Fig. 3. The microstructure of the surface layer of C45 steel after grinding with a depth of $20 \mu \mathrm{m}$. Visible oxidized surface layer approx. $3 \div 4 \mu \mathrm{m}$ thick with numerous cracks, under which plastically deformed grain of perlite and ferrite can be seen

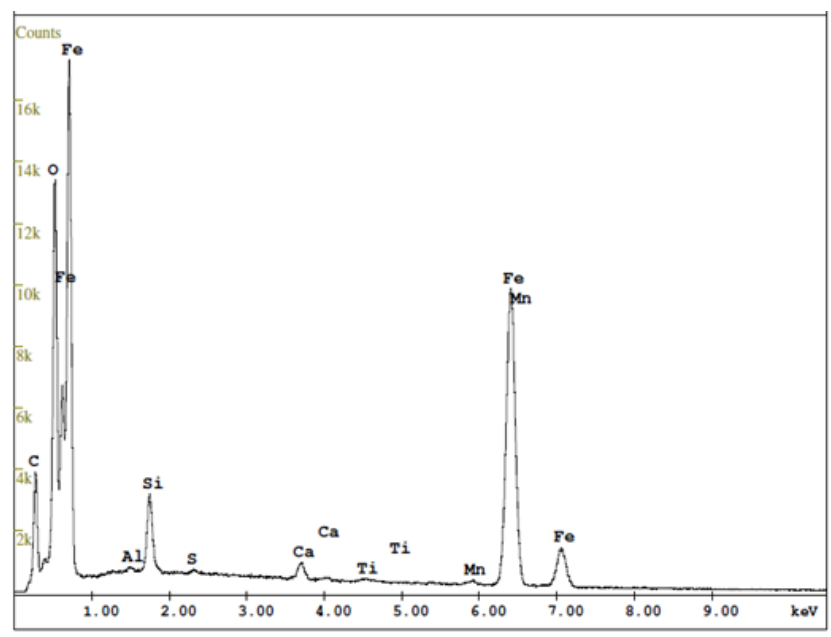

Fig. 4. EDS spectrum for the top layer after treatment of C45 steel with a grinding depth of $20 \mu \mathrm{m}$

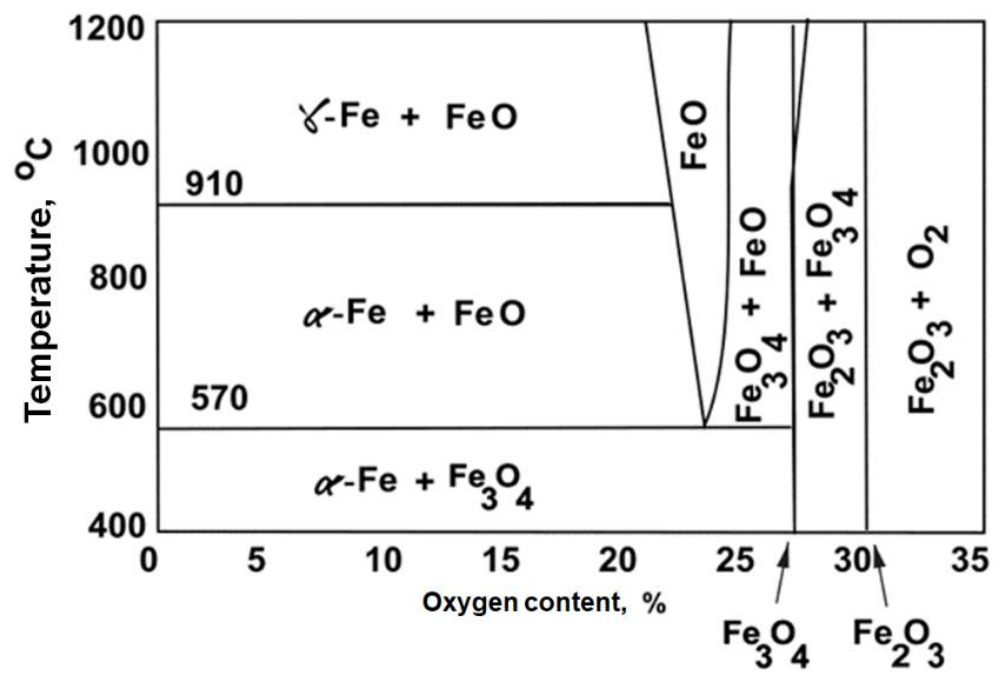

Fig. 5. Iron-oxygen balance system (oxygen content in percent by mass) 


\section{Summary}

Based on the analysis of literature and own research, it can be concluded that carrying out the grinding process with the appropriate parameters allows for shaping the properties of the surface layer as a result of its hardening or plastic deformation of the grains of material. Hardening due to plastic deformation does not require finishing. In addition, in this way, oxide layers can be obtained that are characterized by high hardness and also have anti-corrosive properties. This condition of the surface layer eliminates the adverse phenomena that occur during hard-grinding, and at the same time determines the favorable operational properties of the workpiece.

The authors would like to thank Dr inż. Michał Bartmański for measuring the nano-hardness and Dr inż. Grzegorz Gajowiec for help in taking pictures on a scanning microscope.

\section{REFERENCES}

[1] Haifeng C., Jinyuan T., Weihua Z., Changshun C. "The equal theoretical surface roughness grinding method for gear generating grinding". International Journal of Advanced Manufacturing Technology. 90 (2017): 31373146.

[2] Wilk W., Tota J. "Modern technology of the turbine blades removal machining". $8^{\text {th }}$ International Conference Advanced Manufacturing Operation. Kranevo, 2008.

[3] Chodnicki M., Kaliński K.J., Galewski M.A. "Vibration surveillance during milling of flexible details with a use of the active optimal control". Journal of Low Frequency Noise, Vibration and Active Control. 32, 1-2 (2013).

[4] Nadolny K. „Klasyfikacja procesów szlifowania jednoprzejściowego”. Mechanik. 5-6 (2008): 450-455.

[5] Deja M., Stanisławska A., Szkodo M., Wszelak K. "Influence of parameters of deep grinding on nanohardness and surface roughness of C45 steel”. Mechanik. 11 (2018): 1026-1028, https://doi.org/10.17814/mechanik.2018.11.183.

[6] Salonitis K., “On surface grind hardening induced residual stresses”. Procedia CIRP. 13 (2014): 264-269.

[7] Brinksmeier E., Brockhoff T. "Utilization of grinding heat as a new heat treatment process". CIRP Annals. 45, 1 (1996): 283-286, https://doi.org/10.1016/S0007-8506(07)63064-9.

[8] Brockhoff T., Brinksmeierb E. "Grind-hardening: A comprehensive view". CIRP Annals. 48, 1 (1999): 255260. DOI: https://doi.org/10.1016/S0007-8506(07)63178-3.

[9] Salonitis K., Chryssolouris G. "Thermal analysis of grind-hardening process". International Journal of Manufacturing Technology and Management. 12 (2007): 72-92.

[10] Salonitis K., Chryssolouris G. "Cooling application in grind-hardening operations". International Journal of Advanced Manufacturing Technology. 33 (2007): 285-297.

[11] Salonitis K., Chrondros T., Chryssolouris G. "Grinding wheel effect on grind-hardening process". International Journal of Advanced Manufacturing Technology. 38 (2008): 48-58.

[12] Salonitis K., Stavropoulos P., Kolios A. "External grind-hardening forces modelling and experimentation". International Journal of Advanced Manufacturing Technology. 70 (2014): 523-530.

[13] Venkatachalapathy V.S.K, Rajmohan B. "Experimental studies on the grindhardening effect in cylindrical grinding". Materials and Manufacturing Processes. 18, 2 (2003): 245-259.

[14] Judong L.,. Wei Y, Songwei H., Zhilong X. “Experimental study on grindinghardening of 1060 steel”. Energy Procedia. 16 (2012): 103-108.

[15] Chryssolouris G., Tsirbas K., Salonitis K. "An analytical, numerical, and experimental approach to grind hardening". Journal of Manufacturing Processes. 7, 1 (2005): 1-9.

[16] Hyatt G.A., Mori M., Föckerer T., Zäh M.F., Niemeyer N., Duscha M. "Integration of heat treatment into the process chain of a mill turn center by enabling external cylindrical grind-hardening". Production Engineering. 7, 6 (2013): 571-584.

[17] Wilke T. "Energieumsetzung und Gefügebeeinflussung beim Schleifhärten". PhD Thesis. University of Bremen, 2008.

[18] Doman D., Warkentin A., Bauer R. "Finite element modelling approaches in grinding". International Journal of Advanced Manufacturing Technology. 49, 2 (2009): 109-116.

[19] Jin T., Rowe W.B., McCormack D. "Temperatures in deep grinding of finite workpieces". International Journal of Machine Tools and Manufacture. 42 (2002): 53-59.

[20] Anderson D., Warkentin A., Bauer R. "Experimental validation of numerical thermal models for dry grinding". Journal of Materials Processing Technology. 204, 1-3 (2008): 269-278.

[21] Alonso U., Ortega N., Sanchez J.A., Pombo I., Izquierdo B., Plaza S. "Hardness control of grind-hardening and finishing grinding by means of area-based specific energy". International Journal of Machine Tools \& Manufacture. 88 (2015): 24-33. 
[22] Mahdi M., Zhang L. "Applied mechanics in grinding. Part 7: Residual stresses induced by the full coupling of mechanical deformation, thermal deformation and phase transformation". International Journal of Machine Tools and Manufacturing. 39 (1999): 1285-1298.

[23] Mahdi M., Zhang L.C. "Applied mechanics in grinding-V. Thermal residual stresses”. International Journal of Machine Tools \& Manufacture. 37 (1997): 619-633.

[24] Fischer W.R., Schwertmann U. "The formation of hematite from amorphous iron (III)hydroxide". Clays and Clay Minerals. 23 (1975): 33-37. 